\title{
APPENDIX II. RESULTS OF A SEABEAM SURVEY IN THE LEG 66 TRENCH AREA 1
}

\author{
Jacqueline Roump, ${ }^{2}$ Vincent Renard ${ }^{3}$ Peter Lonsdale, ${ }^{4}$ Jean-François Stéphan, ${ }^{5}$ and Jean Aubouin ${ }^{6}$
}

\section{INTRODUCTION}

Two transits of the French research vessel Jean Charcot in March (TOULAC) and December (PANAC) 1980 from Panama to Acapulco were used to draw a bathymetric map of the Deep Sea Drilling Leg 66 trench area, using the Seabeam system (Renard and Allenou, 1979). The map (Fig. 1, back pocket) actually includes only DSDP Site 488 (Fig. 2) but displays the typical morphology of the trench floor and the lower inner and outer walls of the Middle America Trench (Roump, 1981).

\section{TRENCH INNER WALL}

Most of the inner wall of the Trench has a series of ridges and troughs paralleling the Trench or fanning away from the mouth of Ometepec Canyon (Fig. 3). These crests are the morphologic expression of folds separated by thrust planes, revealed by the UTMSI multichannel seismic profiles across the trench (Figs. 6, 7, and 8 in Shipley et al., 1980) and belonging to the accretionary zone drilled by the Glomar Challenger at Sites 488, 491, and 492 (Moore et al., 1979; Watkins et al., 1981).

The fanning and the importance of the ridges seem related to the supply of sediments through the Ometepec Canyon: The amount of turbidites rapidly decreases away from the mouth of the Canyon (Moore et al., in press), with the height (several hundred meters) and width $(2-3 \mathrm{~km})$ of the ridges creating the fanning on each side of the canyon.

\section{TRENCH FLOOR}

The Trench floor deepens both east and west away from the Ometepec deep sea fan and can be divided into two parts separated by a median channel. The outer part of the floor is flat, but the inner part has a slight slope $(1-2 \%)$ away from the deep sea fan. The inner part of the Trench floor shows low (a few tens of meters), narrow (1-2 km) ridges, subparallel to the Trench axis, which can be interpreted from the seismic profiles (Figs. 6,7 , and 8 in Shipley et al., 1980) as the first folds over

\footnotetext{
I Initial Reports of the Deep Sea Drilling Project, Volume 66.

2 Laboratoire d'Océanologie et Géodynamique, Faculté des Sciences, Université de Bretagne Occidentale, 29283 Brest Cedex, France.

3 Centre Océanologique de Bretagne, B.P. 337, 29273 Brest Cedex, France.

4 University of California, San Diego, Scripps Institution of Oceanography, La Jolla, California.

S Laboratoire d'Océanologie et Géodynamique, Faculté des Sciences, Université de Bretagne Occidentale, 29283 Brest Cedex, France.

6 Département de Géotectonique, Université Pierre-et-Marie Curie,75230 Paris Cedex 05 , France.
}

the first thrust planes of the accretionary zone. The deep sea fan of the Ometepec Canyon conceals tectonic features of the inner Trench floor but displays a complex channel pattern.

\section{TRENCH OUTER SLOPE}

The outer slope of the Trench has shown the most surprising features of the survey on the Middle America Trench: Instead of the expected parallel-to-the-trenchaxis ridges, the Seabeam map reveals oblique crests (Renard et al., 1980), sometimes bearing a volcanic massif $\left(15^{\circ} 48^{\prime} \mathrm{N}-99^{\circ} \mathrm{W}\right)$ or a seamount (southern corner of the map). These NW-SE ridges, bounded by steep scarps, are parallel to the local trend of magnetic anomalies attributable to seafloor spreading (Shipley et al., 1980).

Without more extensive surveys of the adjacent part of the Cocos Plate, it is difficult to resolve how much of the horst-and-graben relief on the outer slope is simply a relict abyssal hill terrain created at the ridge crest and how much results from extensional faulting on the outer wall. Earthquake studies (Chapple and Forsyth, 1979; Dean and Drake, 1978) indicate that normal faulting is now active on the outer slope; perhaps it is proceeding by reactivation of old plate fabric faults and merely exaggerating preexisting relief.

\section{CONCLUSIONS}

The Seabeam reconnaissance of the Trench axis at the Leg 66 transect helps establish the tectonic and depositional environment at DSDP Site 486 in the axial turbidite plain (or distal parts of the Ometepec Canyon fan) and at DSDP Site 488 near the foot of the inner wall. The pattern of block-faulting on the outer slope seems to be inherited from the time of plate accretion. The bathymetry of the inner wall is consistent with sediment off-scraping accompanied by folding and thrust faulting, the amount of off-scraping (or at least the size of accreted ridges) being affected by the amount of sediment supplied to the Trench axis, which decreases away from the mouths of canyons used by turbidity currents.

\section{REFERENCES}

Chapple, W. M., and Forsyth, D. W., 1979. Earthquakes and bending of plates at trenches. J. Geophys. Res., 84:6729-6749.

Dean, B. W., and Drake, C. L., 1978. Focal mechanism solutions and tectonics of the Middle America arc. J. Geol., 86:111-128.

Moore, J. C., Watkins, J. S., Bachman, S. B., et al., in press. Facies belts of the Middle America Trench and forearc region, Southern Mexico: results from Leg 66 DSDP. In Leggett, J. (Ed.), Trench and Forearc Sedimentation and Tectonic in Modern and Ancient Subduction Zones: London (Geological Society of London), 
Moore, J. C., Watkins, J. S., Shipley, T. H., et al., 1979. Progressive accretion in the Middle America Trench, Southern Mexico. $\mathrm{Na}$ ture, 281:638-642.

Renard, V., and Allenou, J.-P., 1979. Sea Beam, multi-beam echosounding in "Jean CHARCOT": description, evaluation and first results. Intern. Hydrog. Rev. Monaco, 56:35-67.

Renard, V., Aubouin, J., Lonsdale, P., et al., 1980. Premiers résultats d'une étude de la Fosse d'Amérique Centrale au sondeur multifaisceaux (Seabeam) C. R. Hebd. Seances Acad. Sci. Ser. D: 137-142.
Roump, J., 1981. Du Fossé d'Amerique Centrale à la plaque Pacifique: étude morphologique au sondeur multifaisceaux Seabeam. Unpublished D.E.A. Memoir, Geology, Université de Bretagne Occidentale, Brest.

Shipley, T. H., McMillen, K. J., Watkins, J. S., et al., 1980. Continental margin and lower slope structures of the Middle America Trench near Acapulco (Mexico). Mar. Geol., 35:65-82.

Watkins, J. S., Moore, J. C., Shipley, T. H., et al., 1981. Accretion, underplating, subduction and tectonic evolution; Middle America Trench, Southern Mexico: results from Leg 66 DSDP. Oceanolog. Acta, 4 (Supplement), 213-224. 


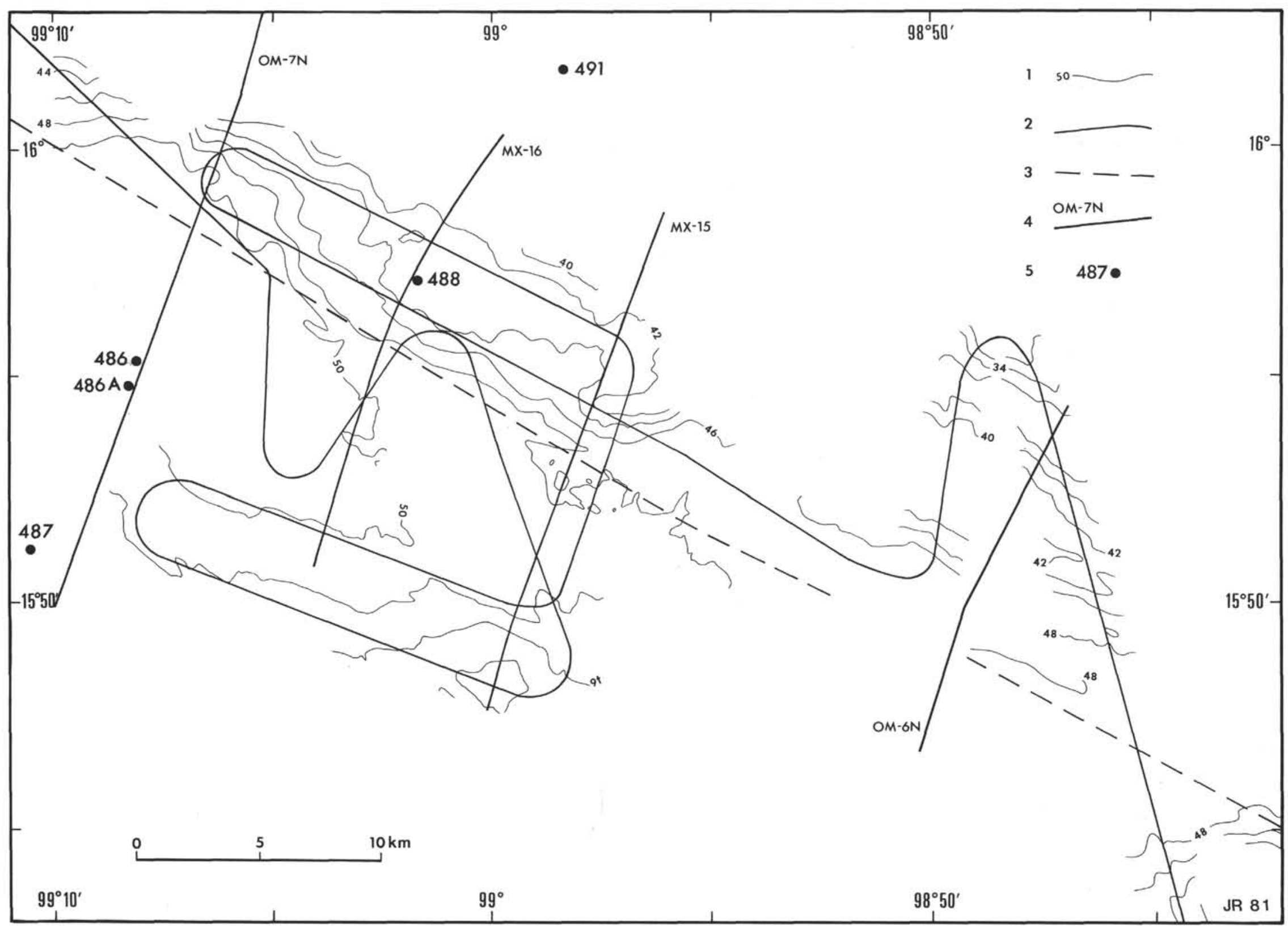

Figure 2. Index map of CNEXO R/V Jean Charcot tracks sailed post-drilling through DSDP Leg 66 area (sites shown) in the Middle America Trench along which Seabeam data were collected. UTMSI multichannel seismic tracks are also indicated. 1: bathymetry in hundreds of meters, contour interval of 200 m; 2: TOULAC transit (March 1980); 3: PANAC transit (December 1980); 4: seismic reflection tracks; 5: IPOD Leg 66 sites. 


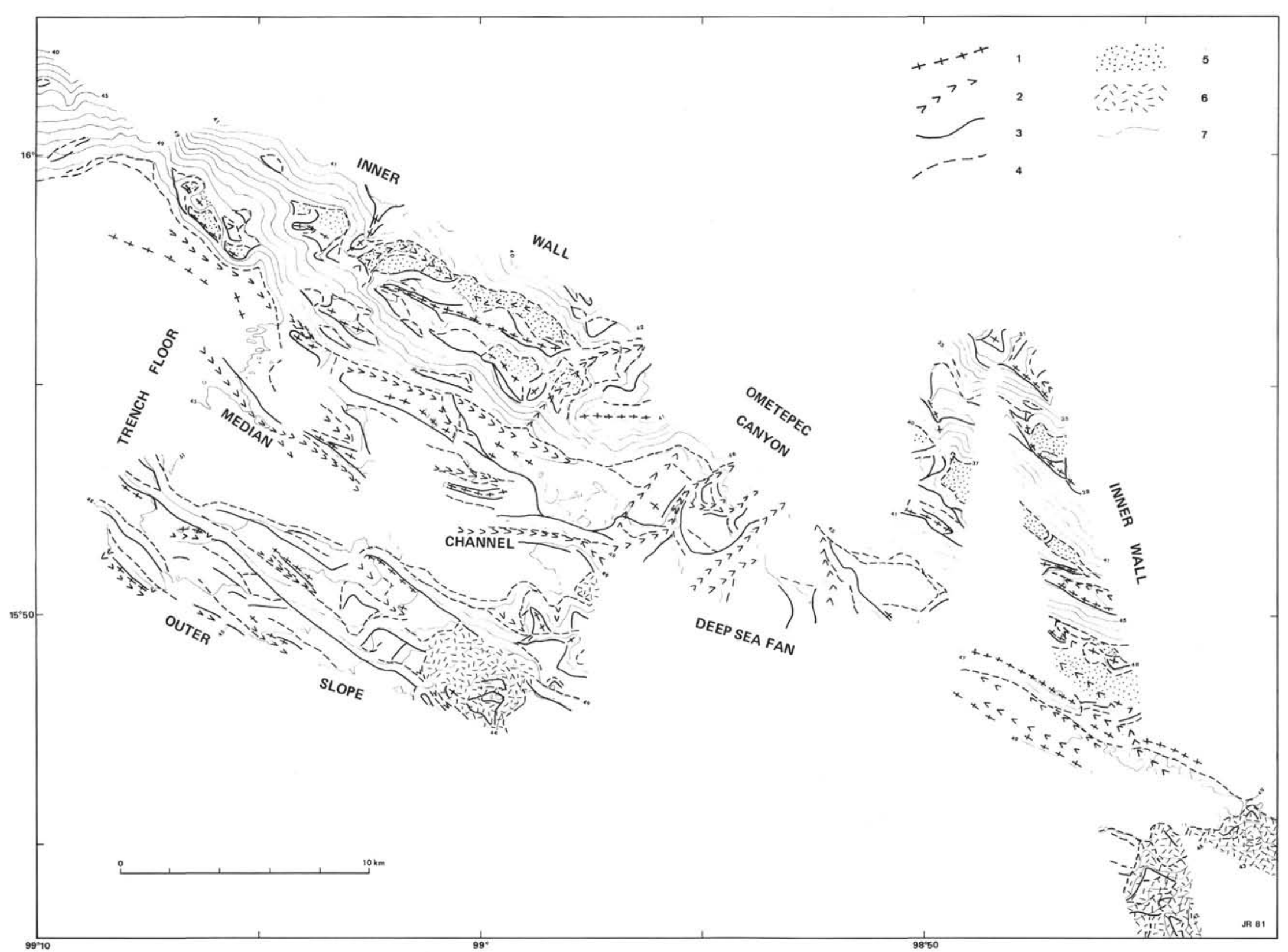

Figure 3. Simplified morphologic map of the Leg 66 Seabeam chart. 1: crests; 2 : channels; 3 : convex change of slope; $4:$ concave change of slope; $5:$ inner wall basins and troughs; 6 : volcanic massifs; 7: bathymetry in hundreds meters, contour interval of $100 \mathrm{~m}$. 